\title{
A Rapid Method of Determining Carpel Numbers in Strawberry Flowers
}

\author{
Fumiomi Takeda ${ }^{1}$, Gary W. Lightner ${ }^{2}$, and Bruce L. Upchurch ${ }^{3}$ \\ U.S. Department of Agriculture; Agricultural Research Service, \\ Appalachian Fruit Research Station, Kearneysville, WV 25430 \\ Additional index words. Fragaria, achene, phyllotaxy, parastichy
}

Strawberry (Fragaria spp.) "fruit" consist of a fleshy receptacle and $<100$ to $>300$ carpels that develop into achenes, the botanical fruit. The number of achenes and weight of mature strawberry fruit are highly correlated (Janick and Eggert, 1968; Abbott et al., 1970; Moore et al., 1970; Webb et al., 1974; Oydvin, 1984). These researchers determined the number of carpels by counting all the achenes on the fruit or by bulk separation of seeds from the receptacle and weighing the seeds. These methods are timeconsuming, laborious, and destructive in the case of the seed weight method. In our laboratory, these methods required $10 \mathrm{~min}$ for each flower. We, therefore, developed a more rapid, nondestructive method of determining carpel number in strawberry flowers.

Where styles were removed, ovaries distributed along the axis of the receptacle were in a definite and repetitive spiraling pattern (Fig. 1). Therefore, the concept of the parastichy, that is, the spiral that can be drawn through all primordia in the order of their origin on the apex, might be extended to inflorescences and, specifically, to the carpel arrangement in strawberry flowers. Relationships may then be expressed between the carpel number in a contact parastichy, defined as primordia that are proximal to one another when they are initiated at the apex (Esau, 1977) (Fig. 1), and the total carpel number.

In Oct. and Nov. 1988, primary (10), secondary $\left(2^{\circ}\right)$, tertiary $\left(3^{\circ}\right)$, and quaternary $\left(4^{\circ}\right)$

Received for publication 13 Apr. 1989. We acknowledge the assistance of Glen Davis, Mark Schiavonne, and Chestina Tharp. The cost of publishing this paper was defrayed in part by the payment of page charges. Under postal regulations, this paper therefore must be hereby marked $a d$ vertisement solely to indicate this fact.

'Research Horticulturist.

${ }^{2}$ Computer Programmer Analyst.

${ }^{3}$ Agricultural Engineer. flowers were collected from 'Tribute' plants in the field. Carpel numbers in a flower were determined by recording the number of styles. Then, carpels in three randomly selected contact parastichies were counted. Carpel number per flower was regressed with the mean carpel number in a spiral in each flower position.

Figure 2 shows the relationship between carpels per flower and carpels per spiral. The goodness-of-fit values were $0.90,0.97,0.79$, and 0.93 for $1^{\circ}, 2^{\circ}, 3^{\circ}$, and $4^{\circ}$ flowers, respectively. Linear regression slope coefficients for $1^{\circ}$ and $2^{\circ}$ flowers were about twice those for $3^{\circ}$ and $4^{\circ}$ flowers, which suggests that a regression equation must be calculated for each flower position. The analysis of data indicates that the postulated relationship was reasonable and offers a feasible basis for estimating the carpel number of strawberry flowers in 1 to $2 \mathrm{~min}$. The method described here will expedite the determination of carpel number in flowers and maybe extended to study the relationship between fruit weight and achene number in strawberry.

\section{Literature Cited}

Abbott, A. J., G.R. Best, and R.A. Webb. 1970. The relation of achene number to berry weight in strawberry fruit. J. Hort. Sci. 45:215-222.

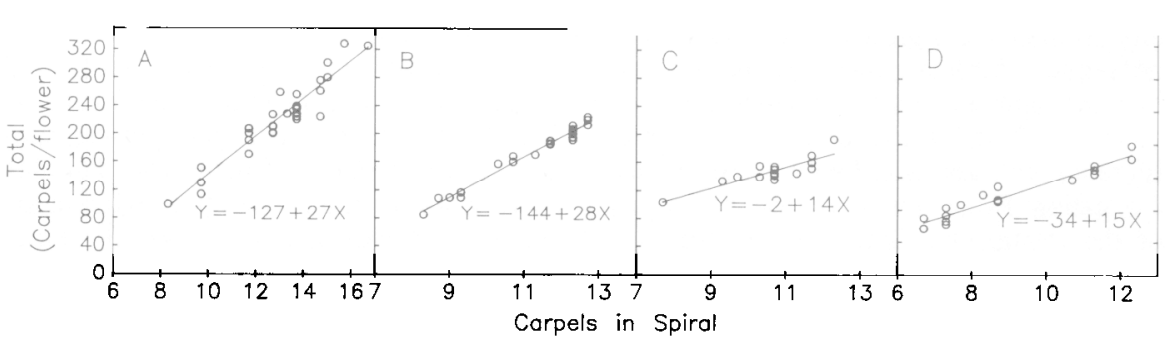

Fig. 2. Relationships between the total number of carpels in primary (A), secondary (B), tertiary (C), and quaternary (D) flowers and the number of carpels in a spiral. Spiral carpel number is the mean of counts taken from three randomly selected spirals. Each point represents the actual carpel numbers per flower. (A) $r^{2}=0.90, \mathrm{n}=30 ;$ (B) $r^{2}=0.97, \mathrm{n}=24$; (C) $r^{2}=0.79, \mathrm{n}=15 ;$ (D) $r^{2}=$ $0.93, \mathrm{n}=13$. 